Kaygl, 20(I)/2021: 171-192. Araştırma Makalesi | Research Article

Makale Geliş | Received: 07.01.2021

Makale Kabul | Accepted: 20.02.2021

Yayın Tarihi | Publication Date: 15.03.2021

DOI: $10.20981 /$ kaygi.889101

\title{
Murad BABADAĞ
}

Öğr.Gör. | Lecturer Bahçeşehir Üniversitesi, Mimarlık ve Tasarım Fakültesi, Endüstriyel Tasarım Bölümü, İstanbul, TR Bahcesehir University, Faculty of Architecture and Design, Department of Industrial Design, Istanbul, TR

ORCID: 0000-0001-6061-9970 muradbabadag@gmail.com

\section{Oğuz HAŞLAKOĞLU}

Doç. Dr. | Assoc. Prof. Dr. İstanbul Teknik Üniversitesi, Mimarlık Fakültesi Fakültesi, Mimarlık Bölümü, İstanbul, TR Istanbul 29 Mayis University, Faculty of Architecture, Department of Architecture, Istanbul, TR ORCID: 0000-0002-3952-6136 ohush@yahoo.com

\section{Bilgi ve Değer Bağlamında “İyi Tasarım” Kavramının İzinin Sürülmesi}

$\ddot{O} z$

Bu makalede, "iyi tasarım" kavramı değer bağlamında, Platonik bir kavram olan Poiesis (yapma/olma) ilişkisi üzerinden, bilginin değere dönüşmesi ve temel değer olarak "iyi” çerçevesinde, sonra da, çağdaş tasarım yaklaşımlarıyla kıyaslanarak irdelenecektir. İnsanın tasarım yoluyla bilgi ve değer bağlamı üzerinden kendisini bir tür olarak nasıl doğayı araçsallaştırarak ayrıcalıklı bir konuma getirdiği, ilk taş alet teknolojisi örneğinde incelenerek ortaya konulmaya çalışılacaktır. Alet yapmak sayesinde bir yandan, yapma bilgisini elde etmek, korumak ve aktarmak yollarını öğrenir ve deneyimlerken, diğer yandan da yaptığı aletin işlevini doğrudan ve tam olarak yerine getirmesi sayesinde de değer kavramına ulaşması irdelenecektir. Böylece 'yapma' eylemi üzerinden bilgi ve değer bağlamının nasıl bizatihi insanın 'olma' esasında kendisini ürettiği araştırılacaktır. Metin boyunca, ilk taş alet teknolojisi örneği kapsamında evrim teorisi ele alınarak, bir tür olarak Homo Sapiens'in Platonik mahiyette yapma-olma/auto-poiésis bağlamı üzerinden nasıl kendine bir Dünya sahnesini açtı̆̆ 1 konusu ele alınmıştır. Aletin nicelik ve nitelik analizlerini yaparak, onun iyi olup olmadığına karar vermek ancak ideolojik ve ekonomik fayda amaçlıdır. Doğadan özgürleşmeyi sağlayan pragmatik değerler, bu araçsallaştırmadan da kurtularak hürleşme (özgürleşmeden farklı olarak) bağlamında özellikle aşılması gereken değerlerdir. Bu anlamda "iyi” yapılmaktan öte, olunan bir şeydir. Yapma-olma vasitasıyla sahip olduğumuz değerler, bizi aynı şekilde, bugüne kadar kullandığımız pragma değerlerinden de hürleştirmelidir. İnsanoğlunun örtük ve esas amacı, kendi doğası gibi görünen bu araçsallaşmadan da hürleşme olmalıdır.

Anahtar Kelimeler: Bilgi, Değer, Tasarım, Taş Alet, Tekhné, Yapma/Olma, İşlev, İyi, Güzel.

\section{Examining the Concept of "Good Design" in the Context of Knowledge and Value}

\section{Abstract}

This article first examines the concept of "good design" in the context of virtue, with respect to the making/becoming relation, as part of knowledge turning into virtue and the concept of 'good', then compares it to the contemporary approaches of design- again with respect to the making/becoming relation. An explanation of how humans privilege themselves as a species by using nature as an instrument by means of design based on the contexts of knowledge and virtue will be attempted. The fact that humans learn and experience the ways of 
acquiring the knowledge of making, of protecting and transferring that knowledge on one hand, on the other hand, they attain the concept of virtue through the tool they have made that functions properly and completely will be discussed. In this way, how the context of knowledge and virtue produces itself in the principle of 'being' that is actually of humans will be investigated through the action of 'making'.

Keywords: Knowledge, Virtue, Design, Stone Tool, Tekhné, Making/Becoming, Function, Good, Beautiful.

Kesin art1k, Daha fazla yakınıp durmayın; Çünkü olagelen, her tarafta Tamamlanma kararında israrlıdır. Sophokles, Oidipous epi Kolōnōi

\section{Giriş}

Makalenin temel meselesi, esastan üç farklı kavramla analiz edilmiş, dolayısıyla bu üç kavram sayesinde kendisini destekleyecek açılardan ele alınmıştır. Bu üç farklı kavramın ilki tasarım eyleminin aktif olarak fail'inin, failleşme süreci olan evrim'le ilgilidir ve metnin konusuyla ilgili olarak birlikte çalışan nörolojik birer yeti olarak hafıza ve hayal gücünün kuvveden fiile geçme sürecini içerir. Diğer kavramlar ise değer bağlamında etik ve bir yapma pratiği olarak tasarım kavramıdır.

Metnin ilk bölümünde ele alınan kavram olan evrim araştırmalarında ilk çarpıcı sonuç şudur; bir bilimsel çalışmada sorulması gereken "ne" sorusu, süreç sayesinde “kim”e dönmüştür.

Burada amaç, fail kavramının potansiyel halden aktif hale hangi yollarla geçtiğinin irdelenmesidir. Etkin olarak eylemde bulunan ve yaptığının bilincinde olan ama eyleminden sorumlu olmayan bir canlı türünden, bilinçli eyleminin sorumluluğunu üstelenen bir türe dönüşümün hikâyesi anlatılmıştır. Ayrıca metnin meselesini doğrudan etkileyen "neden" (amaç), "nasıl”" (süreç) ve "ne için" (sonuç) sorularının da cevapları aranmıştır. Bir kavram olarak evrim kuramı ile başlıyor olmanın birden çok gerekçesi vardır. Örneğin bedenin değişiminin aynı zamanda nörolojik değişimi mümkün kıldığının kanıtlanması, bedenin de hangi gereksinim neticesinde, nasıl değiştiğini açıklaması bakımından önemlidir. 


\section{Evrim ve Failin Doğuşu}

Evrim kuramının bilime konu olmasının tarihsel sürecine bakıldığında görülecektir ki; Homo Sapiens'in evrim süreci 17. Yüzyıl sonlarında yapılan fosil keşiflerinin bilimsel analizleri olarak ele alınmış olsa da, Antik Yunan'da bu süreci fark eden, hisseden ya da doğa gözlemlerinden bu sonuca ulaşan düşünürler olmuştur. Örneğin Milet okulunun önemli figürlerinden Anaksimandros, ilk yaşamın suda başlamış olabileceğini fragmanlarında söylemiştir. Canlıların kökeni ve gelişimi üzerine düşünerek dikkat çekici bir şekilde doğru sonuca ulaşır; “... yeni doğan kara hayvanlarının bakıma muhtaç oluşundan, onların en eski yaşam formu olamayacağı sonucunu çıkarmıştı. Buna karşılık balıklar genellikle yumurtadan çıtıkları andan itibaren aile bakımına ihtiyaç duymuyordu: dolayısıyla hayat suda başlamış olmalıydı" (Schrödinger 2020: 81). Hatta Aristoteles, kendinden önceki filozoflarla ilgili bilgi verirken bu konuya şöyle değinir; "Anaksimandros ,.., insanın başlangıçta kendisinden farklı hayvanlardan türediğini söyledi; diğer hayvanlar çok geçmeden kendi başlarına beslenmeyi öğrenirken, bir tek insan uzun bir emzirme dönemine ihtiyaç duyar" (12 A 10 DK; Eco 2020: 74).

19. yüzyılın başlarında Jean-Baptiste Lamarck'la başlayan evrimi bilimin konusu olarak ele almak yaklaşımı, daha sonra kendi karşı fikirleriyle birlikte hızlanmış, yeni buluntular 1şığında konu birçok açıdan ele alınır. Lamarck ilerlemeci bir gelişim (evrim) yasası olduğuna inanır. Çevresel modifikasyonların kalıtsallığını kabul eden Lamarck özellikle kullanış (yarar/fayda/işlev) ya da kullanışsızlık etkisini önemser. Dönemin bir diğer biyoloğu G. L. L. Buffon evrimi yalnızca çevre koşullarına bağlarken, Lamarck organizmanın ihtiyaçlarına göre organların kullanışını ilk sıraya koyar, faili fayda bağlamında etkin kılar (Saatçioğlu ve Ukray 2014: 322). Lamarck'a göre insan en yüksek mükemmelliğin temsilidir, dolayısıyla canlıları insana yaklaştıkları ölçüye göre değer verir. Lamarck'ın amacı, evrim teorisinin babası sayılan Charles Darwin'in tersine, canlının çevresel faktörlere kendi bedenini ihtiyacına göre doğrudan ve etkin bir biçimde dönüştürerek tepki verdiği kendine içkin özelliklerle evrildiğini ve bunu 
kalıtsal hale getirebildiğini göstermektir. Yaklaşık bir yüzyıl sonra Mendel ve Weismann'ın çalışmaları, Lamarck'ın evrim teorisinin kalbi olan “sonradan kazanılan özelliklerin aktarılması" fikrinin yanlışlığını ortaya çıkarır. Genetik biliminin bu ilk etütleri, çevresel faktörlerin üreme hücrelerindeki genetik koda etki etmeyeceğini ve embriyonun bu genetik koda göre gelişeceğini göstermiştir (Saatçioğlu ve Ukray 2014: 329).

Evrimin temel prensibi Darwin'in ifadesiyle şöyledir; "Bütün durumlarda iki etken vardır: oluşumun (organizmanın) doğası (en önemlisi budur) ve koşulların doğası. Oluşumun doğal özelliği, belirli koşulların etkisinde kalınca, boyun eğiverir ve bütün ya da yaklaşık olarak bütün bireyler aynı tarzda değişiklik geçirir” (2009: 227).

Oluşumun doğasındaki mutasyonun varkalımda nasıl bir avantaja döndüğü ve fizyolojik değişimin nörolojik değişime nasıl yol açtığına dair en dikkat çekici uzuv "El”dir. Darwin kendisinden önce yapılan çalışmalardaki notları derlerken el'in insan evrimindeki önemini fark etmiş ve kitabında buna yer vermiştir. "Sir Charles Bell, 'El, bütün araçların yerini tutar ve akıl ile birlikte insana evrensel egemenlik sağlar" demektedir. El'in evrim sürecindeki önemini görüp bu konuda araştırma yapan diğer bilim adamlarının referanslarından yararlanan Darwin, el'deki mutasyonun başlangıcı için gereken etkileşimin ayakla başlaması gerektiğini de bize gösterir (2009: 63); "Prof. Owen'ın işaret ettiği gibi, yürürken de dururken de dayanak noktası teşkil eden ayak başparmağı, insan bedeninin belki de en karakteristik özelliğidir. Fakat ortalama $2 \mathrm{~cm}$ büyüklüğündeki bir embriyoda ayak başparmağının, diğerlerinden daha kısa olduğunu ve diğerlerine paralel seyredecek yerde, diğer dört ayaklılarda olduğu gibi bir açı teşkil ederek yana doğru seyrettiğini Prof. Wynann gösterdi” der (Darwin 1966: 16). Alıntıların yapıldığı kitabın 1966 yılı Almanca baskısının sonunda yer alan Gerhard Heberer'in son notları çok dikkat çekicidir; "Miyosen devrinde artık genetik bakımından kendine özgü durumları bulunan ve subhuman denilen hominidler iki ayakla yürüme yeteneği kazanırlar. Elleri bu surette hareket esnasında serbest kalır ve başka işler için (kavramak, taşımak, alet kullanmak) kullanmaya başlar....3 milyondan fazla yıl önce, hominidler fillogenisinde en önemli olay meydana gelmektedir: şimdiye 
kadar olan 'alet kullanma' bu hayvan-insan geçiş alanında maksatlı bir sürece dönüşmektedir.” (Darwin 1966: 277). El-beyin ilişkisi vurgusu sadece biyoloji bilimde değil, farklı disiplinlerde de olarak vurgulanmıştır. Örneğin çağdaş tasarım düşünürlerinden Tony Fry (2012: 45) "Bütün aletler bizi ilk alete götürüyor" derken kast ettiği yine el'dir. 'El, bilgiyi barındırır, zihinden (bedene ait olmast itibariyle, MB) daha hızlıdır. Elin durması insanlığın durmasıdır. Beynin gelişmesi kaçınılmazdır ancak elin yetkinliği olmaksızın, beyin aktörü olmayan bir temsil(ci) gibidir” (Fry 2012: 45) diyerek el'in insan evrimindeki önemini vurgulamıştır.

İnsanın evriminde el'in önemi Antik çağda da bilinmektedir, konuyla ilgili bölümde yapılan alıntıların dışında, yine Aristoteles'ten gelen şu saptama da yapmak ve mülk edinmek arasındaki ilişkiyi vurgulaması açısından ilginçtir; "El'in işi şeyleri ele geçirmek ve altında bulundurmaktır” der, ki 2500 yıl sonra Heidegger ayrı kavramı "Das Ding” makalesinde kullanır ve açıklar (Leader 2020: 42).

Evrim teorisinin çalışma mekanizmasını anlayabilmek aslında birbirine bağlı iki kavram olarak zorunluluk ile olumsalliğın aynı anda nasıl birlikte çalışabileceğini görebilmektir. Bu ikilinin doğadaki bir aradalığı gibi tamamen insani bir eylem olan tasarım faaliyetinde de nasıl iç içe olabileceği ve doğa/insan dikotomisine rağmen bu durumun mümkünlüğ̈̈, bölümün sonunda tartışılacaktır.

Bu mekanizmayı anlayabimek için Darwin'in geliştirdiği teoriye geri dönecek olursak zorunluluğun bu teoride nasıl yer aldığını anlarız. Şöyle ki; Darwin’e göre “yeni organlar bir canlıda ancak seyrek olarak sanki özel bir amaçla yaratılmış gibi ortaya çıkar ya da hiçbir zaman çıkmaz. Doğal tarihteki o eski ama biraz abartılmış kuralın gerçekten belirttiği gibi: Natura non facit saltum/ Doğa sıçrama yapmaz." (2009: 321).

"Milne Edward'ın çok güzel belirttiği gibi, doğa çeşitte cömert, yenilikte cimridir. Doğal seçme yalnızca küçük ve ardışık değişimlerden yararlanarak iş görür. Asla ani ve büyük sıçrama yapmaz. Tersine kısa ve güvenli ama ağır adımlarla ilerler" (Darwin 2009: 322).

Burada dönüşümün bir düzen ve devamlılık içeren bir süreç izlemesi gerektiği algısı oluşur. Zorunluluğun, formülün hangi tarafında olduğu çok önemlidir. Bakışımızı 
zorunluluğu görmek için yanlış tarafa çevirmememiz konusunda uyarır; " aynı sınıfın üyelerinin model benzerliğini yararlılıkla ya da 'ereksel nedenler' öğretisiyle açıklamaya çalışmaktan daha umutsuz bir şey yoktur” der. (Darwin 2009: 742). Aslında bu tartışma çok daha eski tarihlerde başlamıştır. Nitekim Antik Yunan'da Atomcu Abdera okulunun kurucusu Leukkipos'un bir metninde "hiçbir şey boşuna gerçekleşmez, her şey açıklanabilir ve her şeyin bir sebebi (logos) vardır" der. Ancak Leukkipos'a göre bu durum bir zorunlulukla gerçekleşir. Bu bağlamda varlığı yadsınan olumsallık, ancak sebep yokluğu olarak var olabilir (ki bu durum mümkün değildir). Hatta aynı okuldan Demokritos'a göre "tesadüf'ten (tyke) söz eden insanlar, bu terimle evrenin deterministik yapısı konusundaki cehaletini gizlemeye çalışırlar” (Eco 2020: 71).

Buradan, Lamarck'ın düştüğü hataya düşmeyip mutasyonun olumsallık/tesadüfiyet üzerinden çalıştığını, dolayısıyla üremenin çok sayıda ve çok hızlı olması gerektiğini, böylece de gen havuzunun zenginleşmesi gerektiği anlaşılmalıdır. Bu ifadeden çıkarılacak sonuç doğanın mekaniğinde, tamamen olumsal ve yeni durumlara uyum sağlayabilecek çeşitli varyasyonların meydana geliyor olması ama bunların hiçbirinin gideceği yerinin/sonucunun öngörülmüyor olmasıdır. Daha temel bir anlatımla belirli bir hedefi veya amacı olmamasıdır.

$\mathrm{Bu}$ durumda elimizde Lamarck'ın evrimde etkin figürüne karşılık Darwin'in (tamamen olmasa da) büyük bir çoğunlukla edilgen figürü bulunmaktadır. Darwin'e göre Lamarck'ın düştüğü tuzak, doğayı ve evrimi Aristoteles'in “ereksel neden”i bağlamında düşünmektir. Pekiyi bu durumda "doğada zorunluluk nerededir?" sorusunun cevabı ise şöyle verilebilir; insan dâhil tüm canlıların varkalım mücadelesinde bulunmaları ve bu yaşam süresince de doğa kurallarına tabi olmalarıdır. Türlerin evrimsel değişimleri, her zaman ve mutlaka enerji dengesi üzerine kuruludur. Eğer ki “enerji kaybı (ki bu kayıp, hayatta kalmak ve üremek amacıyla kullanılacak enerjiden kayıp demektir) edinilecek faydadan büyükse, o davranışı sergilemek, o evrimsel sürece girmek/o yöne doğru evrimleşmek başarısızlıkla sonuçlanacaktır" (Bakırc1 2013: 92). 
Bütün bu açıklamalardan çıkacak olan sonuç Evrimin çeşittilik mekanizmasında olumsallı̆̆ın ve seçilim mekanizmasında da zorunluluğun birlikte karşımıza çıktı̆̆ıdır. Biri olmaksızın diğeri düşünülemez.

Yukarıda açıklanan seçilim mekanizmasında zorunluluk ve olumsallığın doğada iç içe olması, bu karar verme süreçlerinin insan ve hayvanda nasıl çalıştığı sorusunu gündeme getirir. Hayvanda bu seçme/karar verme aşaması varkalıma yönelik olarak işler: içgüdüler vasıtasıyla “iyi olmak” ve “acı çekmemek”tir (Damasio 1999: 202). İnsanda ise içgüdüler haricinde çalışan bir sistem olarak "akıl yürütme ve karar verme terimleri genellikle karar veren kişinin uygun tepki seçiminin dayandırılacağı geçerli çıkarsamalar üretmek için bir mantıksal stratejiye sahip ve akıl yürütme için gereken destek süreçlerinin hazır olduğunu ima eder.” (Damasio 1999: 171). Yukarıda da görüldüğü üzere hayvanlarda sistem insandan daha basittir; varkalımı sağlayan güdü ve içgüdüler, doğuştan gelen tercihler kümesi veya doğal değerler olarak kabul edilebilir. Dolayısıyla şu sonuca ulaşmak mümkündür; içgüdüler canlı organizmayı determine eder, hangi etkiye nasıl tepki vereceği daha önceden davranışlar önceden belirlenmiştir. Doğada tabi olduğu varkalım yasalarının dışında kendi dünyasını kurmaya çalışan insan, belirsizlik içeren olumsallığı, varkalımın gelecekte de devam edebilmesini sağlayabilmek için minimize etmeye çalışır. Bu sebeple de doğadan miras kalan içgüdülerine galip gelmeye çalışır. Metnin başında bahsi geçen hürleşme tam olarak budur.

O halde denilebilir ki; insan için iki tepki türü vardır: önceden determine edilmiş davranışlar ve anlık durumlara göre akıl yürüterek verilebilecek tepkiler. İki sistemin aynı anda bulunması varkalım savaşında bir avantaj haline gelmiş gibi görünür ancak daha sonra bu iki davranış modeli kendi içinde de bir rekabete girmeye başlar. İnsan, tanımı gereği sürekli bu savaşı sürdürendir. Benzer saptamayı yapan Andre LoreiGourhan, "Gesture and Speech" adlı kitabında (1993: 221) bu iki davranış biçimini şöyle tarif eder; "İçgüdü ve zekâ etki ve tesirlerdir, içgüdü önceden belirlenimi, zekâ ise anlık yargı becerisini gösterir”. 
Doğadaki olumsallığın kontrol altına alınabilmesi ancak deterministik bir düzende mümkündür. Düzene gerek olan yerde bir yarg1 ve karara gerek vardır. Bu karara varabilmek için de bir kıstasın olması gereklidir. İşte bu kıstas insan için nedenselliktir. İnsan, neden ve sonucun ardışıklığını kendine temel alan (David Hume’un evrenin çimentosu dediği) nedensellik vasıtasıyla doğayı manipüle edilebildiğini gördüğünde, doğayı kontrol da edebildiği vehmine kapılmıştır. İşte öz’ünün gürleşmesi olarak, doğadan özgürleşme tam olarak budur ve yukarıda ifade edilen hürleşmeden tamamen farklıdır. Metnin ilerleyen bölümlerinde bu fark daha detaylı olarak ele alınacaktır.

Ancak bu bağlamda denilebilir ki bu özgürleşme vasıtasıyla insan, nedenselliğin güçlü aktörü olarak kendini nedenselliğin hâkimi konumuna getirdiği zannına düşer. Prensipte nedensellik boşluk iç(e)remez fakat bütüne hem bedensel hem de zihinsel kısıtlar sebebiyle asla hakim olamayan insan bu ardışıklığın sadece bir fragmanına bakarak sonuç çıkarmaya veya sonuca ulaşmaya çalışır.

Teknoloji ve bilim geliştikçe (özellikle kuantum fiziği ile birlikte), doğanın yaşam alanlarını kuşatan somut ve görülebilir cisimlerinde mikro ölçekte, çıplak gözle görünenden ve Newton fiziğinden bütünüyle farklı davrandığını, büyük ölçekli nesnelere dair deneyimlerimizden hareketle ortaya konulan hiçbir modelin "doğru" olamayacağını görülür (Schrödinger 2020: 140). Somut cisimler söz konusu olduğunda işe yarayan nedenselliğin, mikro ölçekte aslında işe yaramadığı ortaya çıkar. Bu ölçekte gözlemlenen olgular uzay ve zamandaki süreklilik tanımıyla bağdaşmaz. Nedensellik fikri boşluk içeremez, dolayısıyla Darwin'in “doğa sıçrama yapmaz” ifadesi de bir peşi sıralık/artardalık içerdiği için kuantum fiziği açısından artık kullanışsız hale gelir. Bunun da ötesinde bu mikro ölçekteki araştırmalar, özne ve nesne arasındaki sınırları da muğlaklaştırır. Fiziksel eylem daima bir etkileşim eylemidir, daima karşılıklıdır. Bu etkileşime giren taraflarından birini özne diğerini de nesne olarak adlandırmak şüpheli hale gelmiştir. Birine etkin diğerine edilgin demek de işe yaramayacaktır çünkü bu etkileşim tarafların an be an etkin ve edilgen rolü (sıra ile değil, aynı anda) üstlenmesiyle mümkün hale gelir (metnin devamında açıklanacak olan Poiesis bağlamı). $\mathrm{Bu}$ açıklamalardan sonra evrenin bu belirlenimsizlik üzerine tesis edilmiş olma ihtimali 
karşısında etik üzerine fikirlerini beyan eden düşünürler, bu belirlenimsizliğin bireyin etik davranışının sarsılmazlığını etkilememesi gerektiğini söylemek zorunda kalırlar [Cassirer] (Schrödinger 2020: 187).

\section{Araçsal Aklın Doğuşu ve Faillik}

Yine evrim teorisi üzerinden bir analoji yapmak gerekirse doğadaki zorunluluk varkalımdır, olumsallık ise olgusaldır. İnsan araçsal akıl vasıtasıyla kendine ait dünyayı kurduğunda olumsallık en aza indirgenmiş gibi bir izlenim doğar. Yalnızca zorunluluk ve onu mümkün kılan nedensellik (ki aslında olgusaldır) kontrol altına alınınca (?), olumsallık artık öncelikle bedenin tâbi olduğu, eski dünyasına ait bir zafiyet konumuna düşer. Kendini akıldan ibaret sayan İnsan kendi bedenini corpus diye aşağılar (Adorno ve Horkheimer 2010: 74). Bu konu ile ilgili olarak Adorno ve Horkheimer'in “Aydınlanmanın Diyalektiği” (2010: 74) kitabında verdikleri örnek ilginçtir; "İnsanın kendi göğsüne vurması sonradan bir zafer jesti halini almıştır. Bununla muzaffer kişi zaferi her zaman kendi doğasına karşı kazandığını belirtir. Başarı özvarlığı koruyan akı1 tarafından gerçekleşmiştir”.

Hominidlikten Homo ailesine geçişte bir yerlerde ölülerini gömmeye ve yaşl1, yaralı ve sakatlarına bakım sunmaya başladığı bir noktada bu proto-insan evrim teorisinin doğal seçilim prensibine aykırı davranmış ve böylece doğadan kopuş bu yolla başlamıştır. Yaşlılar ve fiziksel olarak güçsüzlerin korunması sosyal evrimi başlatmış, yaşlıların bilgi ve deneyim birikiminden yararlanılmıştır. Bu yolla kültür birikimi sağlanmıştır. Ebeveynler besin peşinde olduğunda çocuklara yaşlılar bakmış, böylece neotenik gerileme, ontogenik ilerlemeyi mümkün kılmıştır (Özkan 2019: 52). Bu sistem sayesinde doğanın temel ilkelerinin tersine çalışan bir sistem olarak zayıfın korunması prensibine dayanan ahlakın nüveleri tesis edilmeye başlamıştır. Böylece poiétik bir olma biçimi türün kendini ve doğayı ehlileştirme, kontrol altına alma veya yönlendirme eylemine tam olarak dönmüştür. İlk bakışta yaşlı ve zayıfın korunması ahlakın temelleri gibi görünse de aslında bu davranış biçimi de varkalımla ilgilidir, iki ebeveynin de çocuklarına bakma zorunluğundan kurtulup ava odaklanabilme firsatı tanır. Dolayısıyla 
bu yolla emek gücü artmaktadır. Fakat bu davranışın yan ürünü olarak "kültür" oluşmaya başlar, çünkü nesiller arası bilgi akışı kolaylaşmış ve devamlılığı sağlanmıştır (sosyal evrim). Böylece doğanın işleyişine karşı çıkan bir sosyal yapı gerçekleştirilir. Doğadan özgürleşmenin bir adımı da bu yolla atılmış olur.

Aslına bakılırsa bu yaşlıların bakımı ve korunması da onların araçsallaştırılmasıdır. Nesiller arasındaki duygusal bağ reddediliyor değildir ancak, sonucun fayda temeli de göz ardı edilemez. Temelinde bu araçsallaştırma ile birlikte tesis edilen bu kültürde herkes birer etken, herhangi bir praksis'in (sonuç odaklı eylem) özne ya da nesnesi, hesaba katılan veya artık katılması gerekmeyen bir şey haline gelir (Adorno ve Horkheimer 2010: 337).

Akıl ilk kullanım anından itibaren, araçsallaşma eğiliminde olduğu için ( ya da zaten ilk kullanımı -varlık amacı itibariye- bu olduğu için), amaç üzerine düşünme pratiği daha zayıf bir girişim olarak kalır. Çünkü aslen amaç her zaman bellidir: varkalım! Bu aklın (ve dolayısıyla o akla sahip hominidin) uymaktan başka şansı olmadığı doğa yasasıdır. İstediği sonuca ulaşmak için her yol mubahtır. Doğadaki her şey (bizzat insanın bedeninden başlayarak kendisi de dahil olmak üzere) araçsallaştırılır, “insanlar kendilerini düşünerek doğadan uzaklaştırırlar ki, doğayı, ona hükmedebilecek şekilde karşılarına alabilsinler" (Adorno ve Horkheimer 2010: 63). Böylece bu zihinsel yetilerin sağladığı kapsamlı düşünme becerisi, amaçları doğrultusunda tüm diğer araçları üretmeye uygun, genel geçer bir araç haline gelir. Daha önce doğa tarafından verilmiş olan içgüdüler araçsal aklın pratiğiyle aynı anda varlığını sürdürür. Yukarıda da açıklandığı üzere, İçgüdü yok olmaz veya aklın varlığı sebebiyle tedavülden kalkmaz. Tam tersi aklı bir araç olarak kullanıp (gizliden gizliye) hükmünü yüceltmeye çalışır. En azından şunu söylemek mümkündür; bu iki yargı sisteminin çalışması her zaman uyumlu bir birliktelik değildir. Burada ifade edilmeye çalışılan aslında doğa'nın yine doğa ile mücadelesi gibi bir şeydir. Doğanın daha sonra hediye ettiği akıl, önceden verdiği içgüdü ile mücadele içine girer. Ahlak, aklın, içgüdüyü devre dışı bırakmak için kurduğu toplumsal bir sistemdir. 
"İnsandaki doğanın yadsınmasıyla birlikte yalnızca dışsal doğa egemenliğinin telos'u değil, insan yaşamının telos'u da darmadağın olur ve saydamlığını yitirir. İnsan kendinin bir kez doğa olduğuna kapalı hale geldi mi uğruna hayatta kaldığı tüm amaçları yani toplumsal ilerleme, tüm maddi ve manevi güçlerin yetkinleştirilmesine yönelik çabalar, hatta bilincin kendisi bile hükümsüz kalır" (Adorno ve Horkheimer 2010: 82).

Kendinde ve kendi için amaç olması gereken akıl (nous), "eleştirel bir öğe olmaktan çıkıp, sırf bir araç olarak var olan doğal düzenin (içgüdüler bağlamında) hizmetine girerse, kendisine seçtiği olumlu olanı istemeden olumsuz ve yıkıcı bir şeye dönüştürür.

Buraya kadar yapılan açıklama evrimsel çizginin doğrultusunda insandaki iç-dış ikilemi ve mücadelesinin nasıl başladığı üzerinedir. Bu iç-dış ikilemi önemlidir çünkü “iç" kendini bir bilinç olarak dişarda(n) oluşturur. Tasarladığı taş alet vasitasıyla bir fail olarak kendini içerde (iç olarak) temsil eder. İçerde temsil edilen fail, bilinç olarak, kendini dışarda(n) izler, kendi varlığını kendine ancak bu failiyetle kanıtlar. Fiilin sürecini kontrol etmek ve hâkim olmak, bilincin kendisini ex-statik olarak tanımasıyla bir ve aynı şeydir. Bu iç-dış ikiliğinin başlangıç noktasını av sürecine bağlamak veya en azından bu kavramla bir analoji kurmak mümkündür. Avda avcı, avını yakalayabilmek için, artık avcı değil, av olmak zorundadır. Av gibi düşünmek ve davranmak, onun her hareketini öngörmeyi kolaylaştırır. Böylece avcı hem kendi hem de başkası olmayı deneyimler. Kendilik bu yolla, bilinçle (hafızada) eylemlerinin faili olarak tutulur/kavranır. Antonio Damasio’ya göre (1999: 104) “doğa olabildiğince etkili biçimde vücudun varkalımını sağlayabilmek için çok etkili bir çözüm yolu bulmuştur: dış dünyayı, ana vücutta neden olduğu değişiklikler bağlamında temsil etmek”. Tony Fry bu iç-dış ilişkisini el ve beyin birlikteliği üzerinden şöyle ifade eder; "El ve aletlerin dünyaya yayılışı, yalnızca beden ve zihin eğilimini dışsallaştırmaz. İç ve dışın, varlık ve dünyanın protez yolunu kurduğunun göstergesidir. Stiegler, diğerleri arasında yalnızca bizim protez varlıklar olduğumuz söyler" (Fry 2015: 101). Yukarıdaki açılamadan çıkarılabilecek bir sonuç da şudur; iç yapandır, dış ise izleyendir ama bu izleyen bir fail olarak aynı anda hem kendini izler hem de yaptığı şeyin kendi zihninde asılı duran modelini izler. İnsan ve hayvan arasındaki fark tam da burada başlar. Anaksimandros 
bir fragmanında bu durumu tespit etmiştir; "insanla hayvan arasındaki fark, insanın duyusal deneyimi hafiza sayesinde bilgiye (sophia) ve teknik beceriye (tekhne) dönüştürebilmesidir" (59 B 21 a DK; Eco 2020: 74). İfade edilmeye çalışılan şudur; hayvan doğadan (dolayısıyla kendi doğasından) sıyrıl(a)madığı için, seyrettiğiyle aynı kalır (iç-dış ayrımı olmaz anlamında). İnsan bu dışta olma yetisi sayesinde bu seyir sırasında hem kendisiyle aynı hem de seyrettiği şey olabilir, [Timaios diyaloğunda Demiourgos'un durumu] ayniyet ve gayriyet bir arada olur (Haşlakoğlu 2016: .69). Bu yolla içinde bulunduğu sahneyi dışardan seyredebilme, ona faillik hissini sağlar. Böylece doğanın da hem içinde hem dışında olma imkânı açılır. Çünkü benlik/faillik bilinci seyir sayesinde açılır. Bilincin kendisi, bir yandan seyrettiği şey haline gelirken öte yandan seyredenin kendilik bilinci de olur. Bu kendini izleyebilme, deneyimin hafızada tutularak öğrenme vasıtasıyla bilgiye dönüşmesine de izin verir.

\section{Poiésis ve Değer İkilemi}

Yukarıda da açıklandığı üzere İnsan doğadan koptuğu andan itibaren, içgüdülerle birlikte çalışan doğal değerler haricinde yeni değerler tesis etmeye ihtiyacı hisseder. Çünkü artık doğanın ona verdiği varkalımsal değerlerden de azat olmuştur (ya da o vehim içindedir).

Değer kavramını pragma bağlamında ele alan araştırmalarda "değer olgusu varoluş ile insana özgü davranışlar arasında soyut bir ilişkidir (Lotze)...nesne ile özne arasındaki ilişkilerin değer kavramını biçimlendirdiğini anlatmaktadır..Parker ise değerlerin sadece eylemlerde ve deneyimlerde yattığını söylemektedir. Nesnelerin kendi başlarına değerleri yoktur; fakat beğenildikleri veya kullanıldıkları zaman değer yaratan potansiyele sahiptirler. Bu nedenle, insanlar bir nesneye değil fakat o nesneden elde edecekleri zevki, faydayı ararlar” (Tapan 1980: 4). Bu yaklaşım (yani değerin pragmatik fayda olarak kabulü) tam olarak Adorno ve Horkheimer'in (2010: 118) ele aldı̆̆ biçimde hesapçı düşünme biçimidir. "Bu da dünyayı öz varlığı koruma hedeflerine göre düzenleyen ve nesneyi salt duyusal bir malzemeden boyunduruk altına alınacak bir malzemeye dönüştürmekten başka bir işlevi olmayan düşüncedir.” Her şey başka bir 
şeye yararı olup olmaması açısından değerlen(diril)ir. İnsan (kendisi de öyle ol[a]madı̆̆ için) dünyasında yer alan diğer şeylerin de kendinde ve kendi için olmasına izin vermez. Dünyasındaki her şeyi sayılabilen/ölçülebilen bir meta/nesneye döndüren hesapç1 düşünme biçimi ile ilgili benzer eleştirileri Heidegger, "Metafizik Nedir" kitabında (2015: 51) ele alır; "hesaplama, tüm var olanı sayılabilen olarak önceden kullanır ve sayma için sayılanı tüketir..hesaptaki tüm hesaplanabilenin, hep önceden hesabınıkitabını yaptığı toplamlardan ve sonuçlardan önce bir bütün olduğunu aklından bile geçirmez”. Tüm bu söylenenleri birlikte ele aldığımızda elimizdeki sonuç şudur; dış dünyayı içerde temsil etmek için yine doğa tarafından hediye edilen nörolojik beceri, amacın değil aracın sorgulandığı bir dünyada, kendi de dâhil olmak üzere her şeyi varkalım uğruna nicelik değerleri üzerinden fayda temelli değerlendirir.

$\mathrm{Bu}$ noktadan itibaren makalenin meselesinin diğer bölümü, etiğin başlangıç noktası olarak bilgi ve değer bağlamında tesisidir. Konunun pragma bağlamında fayda temelli ele alınması, araçsal aklın, kullanılmaya başladığı ilk günden itibaren bir refleks haline gelmiş çalışma biçiminden kaynaklanmaktadır.

Dışardan alınan algısal verilerin ve bu verilere bağlı olgusal sonuçların nedensellik kapsamında işlenmesi ve hafızada (geçmiş zaman kipi olarak) biriktirilmesi varkalımı kolaylaştırır. Çünkü bu depolanan bilgi gelecekte (gelecek zaman kipi olarak) benzer bir durumda kullanılabilir ve bu bilgi sayesinde varkalım devam ettirilebilir. Ancak deneyimin bilgisi zihinde statik bir biçimde ve bir noktada asılı değilidir. $O$ da bilinç gibi an be an temelden itibaren inşa edilir, kendi içinde yaratıcı bir süreçtir. İngiliz psikolog Frederic Barlett'in hafızanın esasında bir yeniden yaratma işlevi gördüğünü ilk kez öne sürerken belirttiği gibi, bu deneyimlerin hiçbiri sabit, tıpkıbasım temsilerle bağdaşmaz (Damasio 1999: 114). Özellikle vurgulanmak istenen detay, hafızadaki bilgilerin kullanılırken yeniden inşa edildiği, bir yaratım faaliyetine tabi olduğudur. Bu özelliğiyle hafızanın hayal gücünden pek bir farkı yoktur. Şöyle ki; "henüz gerçekleşmemiş ve belki de hiç gerçekleşmeyecek bir şeyin imgeleri, doğası bakımından, çoktan olmuş bir şeyin aklımızda kalan imgelerinden farklı değildir; geçmiş olandan çok, olası bir geleceğin anısını oluştururlar” (Damasio 1999: 111). 
Gerçekten de insan bir an sonra ya da uzak gelecekte neler olacağını planlamak için hep geçmişi kullanmakla meşguldür. İşte bu her şeyi yutan aralıksız yaratma süreci, akıl yürütme ve karar verme ile ilgili bir konudur. Karar verme aşaması ise bir seçim yapmadır. Dolayısıyla sorumluluk gerektirir. Seçme sorumluluğu aynı zamanda seçmeme sorumluluğudur. Aristoteles "Eudemos'a Etik" kitabında (2017) bu konu hakkında şunu söyler; "tercih (proairesis) bir seçimdir (hairesis) ama her seçim bir tercih değildir, biri yerine (pro) bir başka şeyi seçmedir. Bu ise incelemeden ve düşünüp taşınmadan bağımsız olamaz" (1226b 5). "Ruhun tartan yanı bir nedene bakabilen yanıdır, nedenlerden biri de ereksel nedendir, nitekim ne için neden" (1226b 25). Demek ki düşünen taşınan kişi hep bir amaç için düşünüp taşınıyor ve hep onunla ilgili olarak yararlı olana baktığı için bir hedefi var, öte yandan hiç kimse amaç için düşünüp taşınmıyor. Nitekim düşünüp taşınan kişi, gözünü amaca dikmişse, onu oraya ne, nasıl götürecektir ya da onun amaçla ilgili olanağı nedir diye düşünüp taşınır” (1227a 10). Alıntıdaki sitemkar ifadeden anlaşılan, artık yalnızca amaca götüren araçların düşünüldüğü, tartılıp biçildiğidir. Dolayısıyla amaç zihinsel süzgeçten geçmez. Hatta bu noktada Aristoteles tarafından tercih ve seçim ayrımı bile yapılır. Fakat amaç'ın mahiyeti yine de sorgulanmadan kalır. Aristoteles yukarıdaki açıklamayı yaptıktan sonra amaç/araç dikotomisindeki problemi fark etmiş olacaktır ki akabinde şu sorgulamayı da yapar; "acaba erdem yanılgısız bir tercihi ve doğru amacı mı gerçekleştirir, yani o yalnızca amaç için tercih edilmesi gereken ne ise onu mu sağlar, yoksa kimilerinin düşündüğü gibi uslamlamayı mı doğru kılar?” (1227b 25). Sonuçta ulaştı̆ğ cevap şudur: "Erdem ile kendine egemen olma farklı şeyler..” (1227b 15).

Kendine egemen olma, temel anlamda içgüdülerine teslim olmama, yani toplumsal yaşamın gereği olan kendi arzu, istek ve ihtiyaçları için diğer bireyleri göz ardı etmeme bilinci olarak kabul edilebilir. Dolayısıyla yasaya tâbî olma veya yasanın dâhil olamadığı durumlarda toplumsal müeyyidelere yani ahlaki normlara uymak olarak düşünülebilir. Bu durumda geriye erdemin “ne'liği’nin sorgulaması kalır. Aristoteles aynı kitapta erdem için de "acaba erdem hedefi mi belirler yoksa hedefle ilgili araçları mı? Biz hedefi belirlediğini kabul ediyoruz çünkü hedefe bir tasımla ya da bir 
uslamlamayla varılmaz, tersine o bir ilkedir, bir başlangıçtır, bir kabuldür" (1227b 2530). Bu cevapla birlikte aklımıza, Immanuel Kant'ın o ünlü maksimi gelir; "İnsan türünün üyeleri, gerek kendi kendilerine, gerekse de türün diğer üyelerine yönelik eylemlerinde insanı amaç olarak görmelidirler. İnsan bir araç olamaz, yalnızca bir amaç olabilir (Bkz. Kant 2020). Bu açıklamalarda erdem'in mahiyetinin net olmaması, hala amaç/araç tartışmasında kesin bir sonuca ulaştırmaz. Aristoteles'te bu sıkışmanın çözümü varmış gibi görünür; "Ereksel neden orta, onun nedeni erdem, erdem de ereksel nedeni nedeni tercih etmek. Tercih amacın kendisiyle değil, o amaca götürenlerle ilgilidir. Zaten bunun için birinin nasıl olduğunu tercihine göre değerlendiriyoruz; yani ne yapıyorsa ona göre değil, ne için / ne adına yapıyorsa ona göre. Öte yandan birisinin nasıl olduğunu tercihe bakarak görmek kolay olmadiğı için, kişinin nasıl olduğunu işlerine bakarak değerlendirmek zorunda kalıyoruz” (1227b 40-1228a 15). Kişinin işi (ergon) olarak ortaya çıkan şey (konumuz gereği alet), kendinde şey olmasına rağmen kendi için değildir, dolayısıyla varlık amacını ifşa edecek bir görünüşe/biçime sahip olması ve bunun ötesinde de başka hiçbir vaatte bulunmaması gerekir. Varlık amacını yerine getirmesi bakımından aldığı değerin dışında (kullanım/değişim) başka hiçbir talepte de bulunamaz. Dolayısıyla kendi nötr (edilgen) tabiatı gereği, yaratıcısının kendine egemen olma savaşının tüm izleri şey’de/alette ifşa olur.

Buraya kadar Aristoteles'in açıklamaları neredeyse metnin başından itibaren savunulan temel meseleyle tamamen örtüşür fakat aradaki dramatik fark şudur: Aristoteles teori ve pratiği birbirinden ayırdığı için düşünce erdemini ve eyleme/pratiğe dayanan karakter eylemini birbirinden ayırır. Sokratik öğretinin temelinde yer alan iyi’nin bilgisi kavramını tamamen reddeder; "Sokrates'in hiçbir şey aklıbaşındalıktan daha güçlü değildir sözü doğru ama aklıbaşındalığının bir bilgi olduğunu söylüyor, bu doğru değil. Çünkü aklıbaşındalık bir erdemdir ve bilgi değildir.” (1246b 35).

Platon ve Aristoteles arasındaki ayrım burada net görülür. Bu iki düşünür, yukarıda adı geçen ergon kavramına da farklı yaklaşırlar. Aristoteles "Eudemos'a Etik" metninde üretici sanatın ergon'unu eylemin kendisi değil de ürünü/sonucu olarak 
tanımlar. Oysa Platon'un poietik bağlamında, Poiei ile ergasetai (başarı), paralel okuma yapıldığında, yapma/etme olarak çevrilen poiesis kelimesinin öz anlamını yapma köküne bağlı olarak tamamla(n)mak, başarmak, ifa etmek gibi düşünmek mümkün olur. Çünkü Poio ve ergazoma fiileri, doğrudan nesneleri olan erga ile geçişli bir bağlantı kurarlar. Erga ergon'un doğrudan nesnesidir (Baker 2015: 8). Sonuç olarak Aristoteles iyi'nin ergon'da yani sonuç üründe olduğunu söyleyerek bir faaliyet biçimi olarak poiesis'in değerini önemsemez görünür ya da ikincil konuma düşürür gibidir. "Ergon'u olan her şey, ergonun hatırına vardır. Ergon, sonuç/amaçtır” (Da Caelo, 2.3,286a8-9; Baker 2015: 30). Hâlbuki bir bitmiş iş olarak ergon/ürün/iş statiktir yani olduğu haliyle kalır, oysa eylemin doğası gereği poiesis dinamik bir süreçtir ve paideia (eğitim) vasıtasıyla gelişme açıktır, içinde potansiyel/imkan olarak mükemmeliyet barındırır. Dolayısıyla poiesis başarma/tamamlamaya bağlı bir yapma faaliyetidir Platon’a göre.

Makalenin temel meselesi olan poiesis'i sadece bir üretme faaliyeti değil, bu üretim vasıtasıyla failin kendini de ürettiği, olma faaliyeti olduğu vurgusu netlik kazanır. Yapma-olma bağlamının Aristoteles'in yaptığı gibi bir teori-pratik ayrımı içeremeyeceği, reflektif bir var olma olarak yapma faaliyetinde "olma" bir sonuç olarak kabul edilirse (ki burada bir sıralılık yoktur, daha çok bir iç içelik vardır) bir yapma teorisi, olmayı tek başına tesis edemeyeceği için, teorisiz bir yapma'nın da mümkün olmayacağı ve teori-pratik ayrımının imkansızlığı ortaya çıkar.

Bütün bu sorgulamaların 1şı̆ğında metnin sacayağının son parçası tasarım kavramına gelindiğinde, evrimin ilk adımının olumsallık olduğu ve mutasyonun protoinsanın varkalımında avantaj haline gelmiş olması bu sorgulamanın çıkış noktası olarak kabul edilebilir. Birbirine etkileşimli bir sistemde bir başlatıcı sayesinde (mutasyon) diğer fizyolojik ve nörolojik değişimlerin mümkün hale geldiğini, bu yolla bu canlının doğanın sunduğu avantajları fark edip kullandığını ve evrimini bu yolla yönlendirdiğini söylemek hatırlanacak olursa insanın evrimi aslında bu sürecin ilk adımı olan olumsallığın iptali çabasıdır. Tasarım kavramının temelinde de tam olarak bu fikir yatmaktadır. Doğada olduğu gibi tasarımda da olumsallık ve zorunluluk iç içedir. Nesne/şey/alet varlığını amacına borçludur. Amaç için gereken işlev, zorunluluğu temsil 
eder fakat biçim/form bu işlev için olumsaldır. Bu açıklamayı güçlendirmek için tasarım tarihinin yakın örneklerinden birine bakmak yeterli olacaktır. II. Dünya savaşı sonrası Alman endüstrisinin önemli markası Braun firmasının 1964-1972 yılları arasında arka arkaya dört farklı saç kurutma makinesi tasarımı üretilir. Hatta bu dört üründen üçü aynı tasarımcının elinden çıkar. İşin ilginci her ürün sanki saç kurutma makinesi tasarımının aslî modeliymiş gibi işlevle doğrudan uyumludur (Less and More 2010: 455). Gösterilen örnekte olduğu gibi işlevi doğrudan tanımlayan biçim kümesi küçük de olsa bir grubu içerir. Bu grubun dışındaki biçimler amaçtan yavaş yavaş sapar dolayısıyla nesnenin/şeyin/aletin varlık sebebi ortadan kalkar veya değişir (artık amaç biçimin ta kendisi olur). Daha da açık bir ifade ile "biçim işlevi izlemez ama gerçekleştirir" ya da “açığa çıkarır/if̧̧a eder”. Bu işlevin gerçekleştirilmesi, aslında onun hal değiştirmesidir. Bu durum İşlevin biçimde/formda pıhtılaşmasıdır.

\section{Poiétik Faaliyet Olarak Tasarım Kavramı}

Tasarımdaki bu biçim sorunsalını anlayabilmek için failin tasarım anındaki fiiliyatının aslında bir seçilim üzerinden yürüdüğü hatırlanması gerekir. Bu seçilimin rasyonel ve/veya duygusal olması başka bir araştırmanın konusudur ancak bu tür bir faaliyette meydana getirilebilecek kombinasyonların sonsuz olduğunu bilmek gerekir. $\mathrm{Bu}$ durumda soru; bu sonsuzluk kümesinden seçilimin nasıl yapıldığıdır. "Yaratmak, (tasarımın yarar bağlamı merkeze alındığında) tam olarak, yararsız bileşimleri değil küçücük bir azınlık olan yararlı birleşimleri oluşturmaktır. Kısır bileşimler failin aklından bile geçmez. Yararlı bileşimlerle bir ölçüde ortak özelliklere sahip olanlar ise fail tarafindan hep engellenir. Her şey sanki fail sanki daha önce bir elemeden geçmiş olan adayları ikinci aşamada sınıyormuş gibi cereyan eder” (Damasio 1999: 201). Dolayısıyla denilebilir ki biçimin sayısı sonsuzdur (olumsallık gereği) fakat işlevi (zorunluluk) en verimli (evrimdeki gibi en fazla kazanç/ en az kayıp) açığa çıkaran form için sınırlı sayıdadır ama hala bir aralığı tanımlar.

“Tahmin ve plan yapmak için gerekli olan, gelecekteki sonuçlarla ilgili zengin senaryoların üretilmesi, koşullara bağlı sınıflandırmalara dayanır. Akıl yürütme 
sürecimiz, amaçları ve bunlara ulaşmak için gerekli zaman ölçülerini hesaba katar. Belirli hedeflere göre ve uygun zaman çerçeveleri içinde, senaryoların gelişimini ve sonuçlarını öngörebilmemiz için kişisel olarak sınıflandırılmış çok zengin bir bilgi hazinesine ihtiyaç duyarız" (Damasio 1999: 195). Böylelikle koşulların tümüne hâkim olunduğu zannı/algısı ile seçimler yapılır. Eylemin sonucunu eyleme henüz başlamadan öngörmek gibi bir yetiyi evrim sayesinde aşamalı olarak geliştiren insan, bu sayede eyleminin de sorumluluğunu üstlenir. $\mathrm{Bu}$ durum tıpkı, yasa karşısında eylemlerinin sorumluluğunu üstlenen birey gibidir. Dolayısıyla eylemin sonucunun suç teşkil etmesiyle kötü olması arasında paralellik kurulabilir. Aristoteles (2017) "İnsanın ilkesi ve hâkimi olduğu nice eylem varsa bunların hem olması hem de olmaması olumsaldır. Bunların oluşması veya oluşmaması ise insana bağlıdır çünkü onların olması ya da olmamasının hâkimi o. Yapmak ya da yapmamak ona bağlı olan nice şey varsa, bunların nedeni de odur" (1223a 5) diyerek failin sorumluluğu hakkında uyarır. Demek ki; İnsan hem karar verme öznesi hem de olasılıkların koşuludur. Bu yaratılış ikiliğiyle duyar, düşünür ve hareket eder. Bu çelişik yaradılışına uygun olarak ve çelişik hayat şartlarına çare bulmak üzere, çelişik hareket eder. Doğasındaki bu ikilik sayesinde hem kendisidir hem de başkası/başka şey (Paulhan 1946: 5). İşte tasarım yapma pratiği geçmiş ve gelecek kurgusu yüzünden yitirdiği şu anın (şimdinin) hem içinde hem de dışında olmaktır. Çünkü aynı anda hem hafıza ve hayal gücü çalışırken, (geçmişin deneyimi ile elde edilen bilgi ve gelecekte olması öngörülen şey arasında) bu eylemi dışarıdan izleyen bilinç/göz eylem anının an be an şahididir/izler/gözler/hafızaya kaydeder. Öte yandan içeride eylemin failidir. Poietik eylem vasıtasıyla, üç zaman kipi, geniş bir "şimdi”nin içinde buluşur.

Failin kendini tanıması bu poietik faaliyet sayesinde mümkün olur. Kant'ın koşulsuz buyruk olarak tanımladığı "öyle eyle ki eylemin evrensel maksim olsun" ifadesi ile Delfi tapınağının kaidesinde yazan “gnothi seauton/kendini tanı” öğüdü bu açıdan aynı bağlamda ele alınabilir. Eyleminin faili olarak ne yaptığını bil ve kendini tanı/bil öğüdü aslında bir ve aynı ifadenin farklı biçimde söylenmiş halleri gibidirler. Eyleminin sorumluluğunu üstlenerek, o eylemin amacını/biçimini ve sonucunu ve 
dolayısıyla da bilfiil kendini, örnek alınması gereken hale getir demektir. Bunun için de fail, eyleminin tasavvur anında önce amacını sorgulamalıdır.

\section{İyi Tasarımın Mahiyeti}

Aristoteles'ten itibaren Episteme (bilgi) ve Etik'in ayrılması, içinde bilme gerektiren her türlü yapma faaliyetinin (içerdiği bilgi mahiyetinde ve sonuçları itibariyle) Etik sorgusunun yapılmasını engeller. Yine Aristotelyen yaklaşımda (yukarıda verilen Aristoteles'in Sokrates eleştirisi hatırlanacak olursa) erdem de bilgiden kopartılmıştır. Dolayısıyla yapma ve bilme, birbirlerinden ayrılmış olarak failin etik sorumluluk alanının dışına çıkar. Artık eylem amacı bağlamında, gerçekleşmeden önce veya yapma anında değil, bittikten sonra sonuç üzerinden değerlendirilir. $\mathrm{Bu}$ ayırımla birlikte ortaya çıkan sorun, yapma/olma ilişsisinin kopmasıdır. İnsanın yaparak olmaktan vazgeçmesi veya unutması gibi sonuçların yanı sıra yapmadan olmaya çalışması gibi liyakat problemleri de ortaya çıkar. Fakat en önemli sorun, yapma sorumluluğunun, o etik sorgu vasitasıyla aynı zamanda yapmama sorumluluğu olduğunu unutmasıdır. Yukarıda açıklandığı şekliyle aklı pragma bağlamında kullanarak ve ona bağlı olarak ürettiği değerlerin tamamı bu durumda sorgulanmaya açık hale gelir. "İyi” tek başına yalnızca bir faydadır artık, dolayısıyla evrensel/değişmez değildir. Zamana/duruma/kişiye göre değişen bir aracın ta kendisidir. $\mathrm{Bu}$ durumda değer bile araçsallaşmıştır. Tasarımda da aynı sorun bire bir izlenir. "İyi tasarım" sonuç ürünün faydası bağlamında sorgulandığında, özellikle 90’larda gündemden düşmeyen iyi tasarım kavramının sorgulanmasına sebep olur. Vilém Flusser'in “iyi silah, iyi (hılı/acısız) öldüren midir?” sorusuna kadar gelinir (Flusser 1999: 55). Çünkü “iyi” artık erdeme bağlı olarak amaçla değil, araçla ilişkilendirilir. Varkalımı sağlamak için neşet eden akıl, ilk andan itibaren araçsallaşma üzerine tesis edildiği için bu karakterini bir türlü değiştiremez. Ulaşabileceği en uç nokta ise şudur; holocaust sırasında çalışma kamplarında yok edilen kurbanların kasık kılları U-bot mürettebatının kalın çorap ihtiyacı için kullanılmıştır (Boucher 2013: 13). Bir araç olarak son derece fayda temelli bir akıl, amaç itibariyle olabileceği en erdemsiz sonuca 
ulaşmıştır. Bu duruma benzer şekilde silahların tasarlanması ve üretilmesinde, malzeme, tedarik ve ikmal metodlarında, stratejilerde araçsal akıl tüm anlamına ulaşır fakat (amaç sorgulanmadığı için) savaşın ve silahların kendi sebebi ve idaresi akıldış1lığa gömülmüştür. Dolayısıyla suç amaç/araç bağlamı düşünülmeden doğrudan "iyi tasarım”a atılmıştır. Amaç/araç ilişkisi bağlamında nazariyat değişmediği sürece, fikriyat da değişmeyecektir ve fatura insanın eylem ve sonuçları itibariyle var olmasını mümkün kılan tasarım kavramına kesilmiştir. Bu şekildeki yapma faaliyetine bağlı sorunları kimi tasarım kuramcıları görmüşlerdir. Nitekim Victor Papanek "Dünyada tasarımdan zararlı meslekler vardır ama bunlar çok azdır” (Papanek 1970: ix) diyerek yapma/olma faaliyetinin erdemsiz sonuçlarını çok sade bir dille ifade etmiştir. 


\section{KAYNAKÇA}

ADORNO, T. \& M. HORKHEIMER (2010). Aydınlanmanın Diyalektiği, çev. Nihat Ülner \& Elif Öztarhan Karadoğan, İstanbul: Kabalcı Yayınevi. Yayıncilik.

ARISTOTELES (2017). Eudemos'a Etik, çev. Saffet Babür, Ankara: BilgeSu Yayınları.

ARISTOTELES (2019). Parva Naturalia, çev. Furkan Akderin, İstanbul: Say

BAKER, S. (2015). "The Concept of Ergon: Towards an Achievement Interpretation of Aristotle's Function Argument," Oxford Studies in Antient Philosophy, 48/2015: 227-266.

BAKIRCI, Ç. M. (2013). Evrim Kuramı ve Mekanizmaları, İstanbul: Evrensel Basım Yayın.

BOUCHER, G. (2013). Yeni Bir Bakışla Adorno, çev. Yetkin Başkavak, Kolektif Kitap.

DAMASIO, A. (1999). Descartes'ın Yanılgısı, çev. Bahar Atlamaz, İstanbul: Varlık Yayınları. Yayınları.

DARWIN, C. (1968). Insanın Türeyişi, çev. Yavuzer Erkoçak, Ankara: Sol

DARWIN, C. (2009). Türlerin Kökeni, çev. Öner Ünalan, İstanbul: Evrensel Basım Yayın. Yayınları.

ECO, U. (2020). Felsefe Tarihi 1, çev. Leyla Tongıuç Basmacı, İstanbul: Alfa

FLUSSER, W. (1999). The Shape of Things, A Philosophy of Design, London: Reaktion Books.

FRY, T. (2012). Becoming Human By Design, London: Berg Publishing.

HAŞLAKOĞLU, O. (2016). Platon Düşüncesinde Tekhné. Sanat ve Felsefenin Ortak Kökeni Üzerine Bir İnceleme, İstanbul: Sentez Yayıncılık.

HEIDEGGER, M. (2015). Metafizik Nedir?, çev. Yusuf Örnek, Ankara: Türkiye Felsefe Kurumu.

KANT, I. (2020). Ahlak Metafiziğinin Temellendirilmesi, çev. Ioanna Kuçuradi, Ankara: Türkiye Felsefe Kurumu.

LEADER, D. (2020). El, çev. Erkan Ünal, İstanbul: İthaki Yayınları.

LOREI-GOURHAN, A. (1993). Gesture and Speech, US: The MIT Press. 
PAULHAN, FR. (1946). Ahlakın Ahlaksızlı̆̆l, çev. Mehmet Naci Ecer, İstanbul: Remzi Kitabevi.

PAPANEK, V. (1985). Design For The Real World, Chicago Academy Chicago Publishers.

UEKI-POLET K. \& K: KLEMP (2009). Less and More, The Design Ethos of Dieter Rams, Berlin: Gestalten Books.

SCHRODINGER, E. (2020). Doğa ve Yunanlılar \& Bilim ve Humanizm, çev. Aynur Başğınar, İstanbul: Babil Kitap.

TAPAN, M. (1980). Mimarlıkta Değerlendirme Aracı Olarak Fayda-Değer Analizi, İstanbul: İTÜ Yayınları. 